\title{
Queratoquistes maxilares: marsupialización
}

\author{
Keratocysts of the jaw: marsupialization
}

D. Martínez Pérez

Resumen: El queratoquiste odontogénico es una tumoración quística cuya cápsula está formada por un epitelio escamoso derivado de la lámina dental o el epitelio odontogénico primordial. Representa un 10\% de todas las lesiones quísticas de los maxilares. Radiológicamente, es raro que presentes reabsorciones radiculares. El diagnóstico está basado en las características histológicas. El diagnóstico diferencial más importante es el quiste folicular que se caracteriza por un revestimiento escamoso de espesor variable. El tratamiento de los queratoquistes odontogénicos es objeto de constante discusión ya que la tasa de recidiva publicada es elevada (en torno al 30\%). El tratamiento estándar es la enucleación, pero dado que la cápsula es típicamente fina y friable, se suele fragmentar durante la extirpación. La resección incompleta de la cápsula así como la presencia de microquistes en el tejido conectivo circundante predispone a la recidiva o persistencia de la tumoración. La alternativa es el tratamiento por medio de descompresión y marsupialización.

Palabras clave: Queratoquistes; Maxilares; Tratamiento quirúrgico.

Recibido: 25.07.2006

Aceptado: 31.07.2006

\section{Introducción}

El queratoquiste odontogénico es una tumoración quística cuya cápsula está formada por un epitelio escamoso derivado de la lámina dental o el epitelio odontogénico primordial. Representa un 10\% de todas las lesiones quísticas de los maxilares. El 50\% de estos quistes se asocian con piezas incluidas. Normalmente no suelen presentar dolor ni parestesias. Radiológicamente, es raro que presentes reabsorciones radiculares. Es localmente agresivo, recidiva con frecuencia y, ocasionalmente, se asocia con displasia epitelial o incluso

Cirujano Oral y Maxilofacial. Fundación Jiménez Díaz, Madrid, España

Correspondencia:

Fundación Jiménez Díaz

Avda. de los Reyes Católicos 2. 28040 Madrid, España

Email: dmartinez@fjd.es

\begin{abstract}
The odontogenic keratocyst is a tumor-like cystic with a capsule that is formed of squamous epithelium originating from dental lamina or from primordial odontogenic epithelium. Radiologically, radicular resorption is rare. The most important differential diagnosis is the follicular cyst that has a characteristic squamous coating of a variable thickness. Treatment for odontogenic keratocysts is the object of constant discussion as the rate of recurrence published is high (around 30\%). The standard treatment is enucleation, but given that the capsule is very fine and friable, it tends to break into fragments during extraction. Incomplete resection of the capsule, as well as the presence of microcysts in the surrounding connective tissue, makes recurrence or tumor persistence more likely. The alternative is treatment by means of decompression and marsupialization.
\end{abstract}

Key words: Keratocysts; Jawbones; Surgical treatment.

\section{Introduction}

The odontogenic keratocyst is a tumor-like cystic with a capsule that is formed of squamous epithelium originating from dental lamina or from primordial odontogenic epithelium. It represents $10 \%$ of all cystic lesions of the jaws. Of these cysts $50 \%$ are associated with an embedded tooth. Normally there is neither associated pain nor paresthesia. Radiologically, radicular resorption is rare. It is locally aggressive, recurrence is common and occasionally associated with epithelial dysplasia and even with epidermoid carcinoma. A mutation of the tumor suppressor gene PATCHED can be appreciated with a certain frequency in the hereditary forms as well as in the sporadic forms of parakeratinized keratocysts. As a result of this it can be considered as a sort of tumor, unlike other dentigerous cysts. ${ }^{1}$

The diagnosis is based on the histologic characteristics: Fine stratified squamous epithelium with basal cells in a palisade arrangement, a smooth interface with the stro- 
carcinoma epidermoide. Con cierta frecuencia se aprecia una mutación del gen supresor de tumores PATCHED tanto en las formas hereditarias como en las formas esporádicas de queratoquistes paraqueratinizados. Este hecho se puede interpretar como que se trata, a diferencia de otros quistes dentígeros, de un tipo de tumor. ${ }^{1}$

El diagnóstico está basado en las características histológicas. Un epitelio fino estratificado escamoso con células basales en empalizada, con una interfase suave con el estroma, sin crestas, y una superficie ondulada con paraqueratina. Las células paraqueratinizadas superficiales se tiñen intensamente con queratina 10-una citoqueratina de bajo peso molecular que se expresa en un subtipo de queratinocitos en la mucosa gingival normal. ${ }^{2}$ Esta característica inmunohistoquímica se puede aplicar a los diagnósticos citológicos. ${ }^{3}$

El diagnóstico diferencial más importante es el quiste folicular que se caracteriza por un revestimiento escamoso de espesor variable, a veces con crestas, células dispersas con mucina y algunas células ciliadas. Sin embargo, cuando un queratoquiste se inflama puede ser indistinguible de un quiste dentígero.

El 5\% de los queratoquistes se asocian con el síndrome del nevus de células basales o síndrome de Gorlin (autosómico dominante) que se caracteriza por múltiples basaliomas, múltiples quistes odontogénicos, anomalías esqueléticas tales como costillas bífidas, y ocasionalmente otros tumores como meduloblastomas o fibromas ováricos.

\section{Discusión \\ Tratamiento de los queratotoquistes}

El tratamiento de los queratoquistes odontogénicos es objeto de constante discusión ya que la tasa de recidiva publicada es elevada (en torno al 30\%).

El tratamiento estándar es la enucleación, pero dado que la cápsula es típicamente fina y friable, se suele fragmentar durante la extirpación. La resección incompleta de la cápsula así como la presencia de microquistes en el tejido conectivo circundante predispone a la recidiva o persistencia de la tumoración. Otros métodos empleados son curetaje, la crioterapia,la ostectomía periférica y la aplicación de sustancias químicas fijadoras al hueso circundante.

La alternativa es el tratamiento por medio de descompresión y marsupialización. La descompresión impide que el quiste siga expandiéndose, ya que parece que el crecimiento de los quistes responde a una combinación de presión osmótica y reabsorción por presión y a la liberación de prostaglandinas y factores de crecimiento. La descompresión puede llevarse a cabo por medio de la simple aspiración de líquido o bien convirtiendo la cavidad quística en una bolsa que se abre a otro medio (marsupialización: derivado del griego marsupial- bolsa). Los quistes mandibulares se marsupializan a la cavidad oral, los maxilares pueden abrirse a la cavidad oral o bien ocasionalmente también a la cavidad nasal o al seno maxilar.

El tratamiento por medio de descompresión y marsupialización se describió a finales del siglo XIX en la literatura alemana por Partsch. En ese momento era el tratamiento de elección, ya que era todavía la era preantibiótica y la enucleación quística con frecuencia derivaba en dehiscencias e infecciones locales. Con el advenimiento de los antibióticos, la enucleación con sutura directa de la mucosa pasó a ser el tratamiento habitual de estas lesiones. ma, no crests, and a parakeratinized wavy surface. The superficial parakeratinized cells become intensely stained with keratin 10 - a low molecular weight cytokeratin that is expressed in normal gingival mucosa..$^{2}$ This immunohistochemical characteristic can be applied to cytologic diagnoses. ${ }^{3}$ The most important differential diagnosis is the follicular cyst that has a characteristic squamous coating of a variable thickness, sometimes with crests, dispersed cells with mucin and some ciliated cells. However, when a keratocyst is inflamed it can be indistinguishable from a dentigerous cyst.

Of the keratocysts, $5 \%$ are associated with the Basal cell nevus syndrome or Gorlin syndrome (autosomal dominant condition), which is characterized by multiple basaliomas, multiple odontogenic cysts, skeletal anomalies such as bifid ribs, and occasionally other tumors such as medulloblastomas or ovarian fibromas.

\section{Discussion \\ Keratocyst treatment}

Treatment for odontogenic keratocysts is the object of constant discussion as the rate of recurrence published is high (around 30\%).

The standard treatment is enucleation, but given that the capsule is very fine and friable, it tends to break into fragments during extraction. Incomplete resection of the capsule, as well as the presence of microcysts in the surrounding connective tissue, makes recurrence or tumor persistence more likely. Other methods employed are curettage, cryotherapy, peripheral ostectomy and the application of chemical substances that attach to the surrounding bone.

The alternative is treatment by means of decompression and marsupialization. Decompression stops the cyst from expanding, and it would appear that the growth of the cysts responds to a combination of osmotic pressure and resorption through pressure, and to the release of prostaglandins and growth factors. Decompression can be carried out by means of simple aspiration of liquid or by converting the cystic cavity into a sac that opens to another medium (marsupialization: derived from the Greek marsupial meaning bag). Mandibular cysts are marsupialized to the oral cavity, those of the jaw can be opened to the oral cavity or occasionally to the nasal cavity or to the maxillary sinus. Treatment by means of decompression and marsupialization was described at the end of the XIX century in the German literature by Partsch. At that moment it was the treatment of choice, as it was still the preantibiotic era, and cystic enucleation with frequency lead to dehiscence and local infection. With the advent of antibiotics, enucleation with direct suturing of the mucosa became the habitual treatment for these lesions.

In 1991 Brondum and Jensen published a long-term following of 44 odontogenic keratocysts. The global rate of recurrence was $18 \%$, but a small group of 12 patients that had been treated with decompression and marsupialization, showed no recurrence during a follow-up period of 7 to 17 
En 1991 Brondum y Jensen publicaron un seguimiento a largo plazo de 44 queratoquistes odontogénicos. La tasa global de recidivas era un $18 \%$, pero en un pequeño grupo de 12 pacientes que habían sido tratados con descompresión y marsupialización no había ninguna recidiva en un periodo de seguimiento de 7 a 17 años. Posteriormente este mismo grupo publicó sus resultados en un total de 23 pacientes tratados con descompresión e irrigación, con la aparición de recidivas en 2 de 23 casos $(8,7 \%){ }^{4}$

Técnicamente, la marsupialización consiste en practicar una apertura formal de un centímetro de diámetro, y si es posible suturar la mucosa oral a la pared quística. La apertura debe mantenerse abierta bien por medio de un taponamiento o mediante la inserción de un stent que impida el cierre. En la mandíbula la tendencia a que la apertura se cierre es mayor que en el maxilar. El proceso debe ir seguido de al menos dos irrigaciones diarias con clorhexidina. Ocasionalmente, la marsupialización lleva a la completa resolución de la lesión en el plazo de unos meses. Con el tiempo se reduce el tamaño de la lesión y en la mayoría de protocolos se lleva a cabo una enucleación pasados 10-12 meses.5,6 En el momento de la quistectomía, la cápsula está engrosada y se adhiere menos al hueso, y en un $60 \%$ de los casos no presenta ya las características histológicas del queratoquiste odontogénico, y es negativo para la citoqueratina 10. Esto puede deberse a una metaplasia del revestimiento del quiste o al crecimiento de la mucosa oral. ${ }^{7}$ La tasa de recidiva publicada con este método es inferior al $10 \%$.

La selección de casos para este método debe ser cuidadosa, ya que el paciente debe llevar a cabo unas dos irrigaciones diarias durante varios meses. Fracasa sobre todo en aquellos casos multiloculados en que quedan cavidades que no están abiertas a la cavidad oral. Este hecho puede minimizarse eliminando cuidadosamente todos los tabiques en la cirugía de descompresión.

\section{Desventajas}

- Dos intervenciones.

- Mantenimiento de una cánula o Stent durante varios meses.

- Lavados repetidos durante varios meses.

\section{Ventajas}

- Engrosamiento de la cápsula (mayor facilidad de extirpación).

- Disminución del tamaño de la lesión (menor riesgo de lesión de estructuras y de fractura).

- Menor tasa de recidiva.

\section{Bibliografía}

1. August M, Caruso PA, Faquin WC. Case 40-2005. NEJM 2005;353:2798-850.

2. Mac Donald AW, Fletcher A. Expression of cytokeratin in the epithelium of dentigerous cysts and odontogenic keratocysts: an aid to diagnosis. J Clin Pathol 1989;42:736-9.

3. August M, Faquin WC, Ferraro NF, Kaban LB. Fine needle aspiration biopsy of intraosseous jaw lesions. J Oral Maxillofac Surg 1999;57:1282-6.

4. Brondum N, Jensen VJ. Recurrence of keratocysts and decompression treatment. A long term follow up of forty four cases. Oral Surg Oral Med Oral Pathol 1991;72:265.

5. Pogrel MA: Marsupialization as a definitive treatment for the odontogenic Keratocyst. / Oral Maxillofac Surg 2004;62:651.

6. Pogrel MA. Treatment of keratocysts: the case for decompression and marsupialization. / Oral Maxillofac Surg 2005;63:1667-73.

7. August M, Faquin WC, Troulis MJ, Kaban LB. Dedifferentiation of odontogenic keratocysts epithelium after cyst decompression. J Oral Maxillofacial Surgery 2003; 61:678-83. years. Later this same group published its results regarding a total of 23 patients treated with decompression and irrigation, with recurrence appearing in 2 of the 23 cases (8.7\%). ${ }^{4}$

Technically marsupialization consists in practicing a formal opening with a diameter of one centimeter and, if possible, the oral mucosa is sutured to the cystic wall. The opening should be kept well open by means of a plug or by inserting a stent to prevent closure. There is a greater tendency in the mandible for the aperture to close than in the maxilla. The process should be followed by at least two daily rinses with chlorhexidine. Occasionally, marsupialization leads to the complete resolution of the lesion in the space of a few months. Over time the size of the lesion lessens and in most protocols enucleation is carried out after 10-12 months. ${ }^{5,6}$ When the cystectomy is carried out the capsule is swollen and it sticks less to the bone. In $60 \%$ of cases the histological characteristics of the odontogenic keratocyst are no longer observed, and it is negative for cytokeratin. ${ }^{10}$ This could be due to a metaplasia of the cyst coating or to the growth of the oral mucosa. ${ }^{7}$ The rate of recurrence published with this method is less than 10\%.

The selection of cases for this method should be made carefully as the patient has to rinse twice a day for several months. Failure occurs particularly with multiloculated cases when there are cavities that are not open to the oral cavity. This can be minimized by carefully eliminating all the walls during decompression surgery.

\section{Disadvantages}

- Two interventions.

- Maintaining a tube or Stent over several months.

- Repeated rinses over several months.

\section{Advantages}

- Thickening of the capsule (removal is made easier).

- Reduction of the size of the lesion (less risk of structure damage or fracture).

- Lower recurrence rate. 